\title{
The Availability, Extent and Quality of Sustainability Reporting by Malaysian Listed Firms: Subsequent to Mandatory Disclosure
}

\author{
Hafizah Abd-Mutalib (Corresponding Author) \\ Senior Lecturer, Department of Commerce \\ Sultan Abdul Halim Mu'adzam Shah Polytechnic, Jitra, Kedah, Malaysia \\ E-mail: hafizah.mutalib@yahoo.com \\ Che Zuriana Muhammad Jamil \\ Associate Professor, School of Accountancy, College of Business \\ Universiti Utara Malaysia, Sintok, Kedah, Malaysia \\ Wan Nordin Wan-Hussin \\ Professor, Othman Yeop Abdullah Graduate School of Business \\ Universiti Utara Malaysia, Sintok, Kedah, Malaysia
}

Received: August 9, 2014 Accepted: Oct. 7, 2014 Published: December 1, 2014

doi:10.5296/ajfa.v6i2.6108 URL: http://dx.doi.org/10.5296/ajfa.v6i2.6108

\begin{abstract}
The purpose of this study is to examine the availability, extent and quality of Sustainability Reporting (SR) by Malaysian firms subsequent to the mandatory disclosure. Based on an across-industry sample of 300 firms in 2011, the results indicate that despite the mandatory disclosure, $3 \%$ of the sampled firms failed to make such reporting. Furthermore, in both aspects of extent and quality, human-related sustainability engagement, which consists of the workplace and community themes are found to be the favorite themes to be reported. Meanwhile, firms in the infrastructure, finance and plantation industries perform the best of extent and quality of SR, while firms in hotel industry marks the poorest in quality and lowest in extent of SR.
\end{abstract}

Keywords: Sustainability Reporting, Malaysia, Extent, Quality 


\section{Introduction}

The term "Sustainability" has become one of the important idioms in the business vocabulary. The World Commission on Environment and Development (1987), states that "Sustainable development is development that meets the needs of the present without compromising the ability of future generations to meet their own needs", as such, the principles of sustainability is to ensure that our actions today do not limit the range of economic, social and environmental options open to future generations (Elkington, 1997). SR may be interchanged with many other terms, such as Corporate Social Responsibility (CSR), which refers to the voluntary actions taken by a company to address economic, social, and environmental impacts of its business operations and the concerns of its principal stakeholders (Christensen, Peirce, Hartman, Hoffman, \& Carrier, 2007), or Triple Bottom Line (TBL), a concept that expresses the idea that business firms or other organizations create value in multiple dimensions, which are in the economic, social and environmental value added (Elkington, 2006). Despite the various terms associated to sustainability, the ultimate focus is the same, which is to preserve the current world condition for the benefit of future generations through fulfilling the needs of not only the shareholders, but also the stakeholders as well, by complementing the financial performance with environmental and social commitments.

The engagement to sustainability activities is seen as an important agenda to be considered as such engagement may result in the sustainability of not only the business firms, but also the sustainability of the environment in which they operate. The world today has witnessed the massive destructions on the environment which ends up with environmental disasters and human-related issues such as child-labour and workplace discrimination which resulted from the lack of commitments to preserve sustainability by business firms. In order to cope with such issues, sustainability engagement has become a vital plan in dealing with such matters. In Malaysia, one of the commitment posed by the Government towards sustainability engagement is to require such engagement to be disclosed in the annual reports by Malaysian listed firms (Ministry of Finance, 2006). This requirement has also been gazetted in the Bursa Malaysia Listing Requirements under Appendix 9C, Para 29, as such, starting from the year 2007, every Malaysian listed firm needs to disclose their sustainability or CSR activities in their annual reports.

The purpose of this study is to examine the availability, extent and quality of SR by Malaysian listed firms in 2011, which marks 5 years subsequent to the mandatory disclosure. Prior to the mandatory disclosure, the level of SR by Malaysian firms are not extensive (Teoh $\&$ Thong, 1984), plus poor in quality and low in quantity (Thompson \& Zakaria, 2004). Furthermore, Malaysian firms are found to concentrate on the philanthropic and public relations aspects of sustainability engagement ( $\mathrm{Lu} \&$ Castka, 2009), and least in environmental engagement (Thompson \& Zakaria, 2004). The reporting also concentrates on reporting good news on sustainability commitments (Haron, Yahya, Manasseh, \& Ismail, 2006; Nik Ahmad, Sulaiman, \& Siswontoro, 2003; Thompson \& Zakaria, 2004), which implies that sustainability reporting is more for improving corporate image (Nik Ahmad, et al., 2003). With respect to the location for reporting, there is no specific location identified, 
where most firms report in the Chairman's Statement and Operations Review (Nik Ahmad, et al., 2003). Additionally, the nature of reporting is merely narrative or a declarative statement (Haron, et al., 2006; Nik Ahmad, et al., 2003). One of the reasons for the poor performance of SR is due to lack of legislations and regulations on sustainability disclosure (Teoh \& Thong, 1984; Thompson \& Zakaria, 2004), thus it is crucial to examine if the SR requirement put forth by the Malaysian Government and Bursa Malaysia starting in the year 2007, may enhance the level of SR by Malaysian listed firms.

Despite the numerous studies done to determine the availability of SR by Malaysian firms (Muhammad Jamil, Alwi, \& Mohamed, 2003; Nik Ahmad, et al., 2003; Teoh \& Thong, 1984; Thompson \& Zakaria, 2004), the results refer to the availability of SR prior to the mandatory disclosure, while studies that refer to the period subsequent to the mandatory disclosure has concentrate on large size firms (Zainal, Zulkifli, \& Saleh, 2013). Prior research has also focus on certain industries, for instance, finance industry (Abdul Rahman, Md Hashim, \& Abu Bakar, 2010; Singh, Yahya, Amran, \& Nabiha, 2009), non-financial industries (Haniffa \& Cooke, 2005; Janggu, Joseph, \& Madi, 2007; Kasim, 2007; Mohd Ghazali, 2007), and concentrates to environmental engagement (Kasim, 2007; Othman \& Ameer, 2010; Smith, Yahya, \& Amiruddin, 2007). Moreover, past researches have either use the extent measurement, whether by words (Haniffa \& Cooke, 2005) and by sentences (Abdul Rahman, et al., 2010; Amran \& Devi, 2007; Janggu, et al., 2007) or quality measurement (Saleh, Zulkifli, \& Muhamad, 2010, 2011) for SR. To compliment these prior researches, the current study provides relevant input in these four contributions: (1) using a more recent data, which is the SR in the 2011 annual reports; (2) examine the availability of SR by Malaysian firms subsequent to the mandatory disclosure, where limited evidence has been found; (3) across-industry sampling and analysis; and (4) measurement of SR in four focal themes, which are the environment, workplace, marketplace and community themes, using both the extent and quality measures.

The rest of the paper progresses as follows. The next section reviews the related literature on SR reporting in Malaysia. This is followed by the methodology, and the findings are discussed thereafter. The concluding remarks summarize the main results, highlight the study limitations and suggest avenues for future research.

\section{Literature Review}

\subsection{Sustainability}

The term "sustainability" is connected to the classic definition of "sustainable development" by World Commission on Environment and Development (1987), which states that "Sustainable development is development that meets the needs of the present without compromising the ability of future generations to meet their own needs". The principle of sustainability is to ensure that our actions today do not limit the range of economic, social and environmental options open to future generations (Elkington, 1997). From the notion of sustainability, emerged other related terms; where among the most popular terms are TBL and CSR. The former expresses the idea that business firms or other organizations create value in multiple dimensions, i.e., in economic, social and environmental dimensions 
(Elkington, 2006), while the latter refers to the voluntary actions taken by a company to address economic, social and environmental impacts of its business operations, and the concerns of its principal stakeholders (Christensen, et al., 2007). Besides TBL and CSR, sustainability also refers to social responsiveness, social performance, public policy, CSP, business ethics or stakeholder management (Carroll, 1991; Mohammed, Alwi, \& Muhammad Jamil, 2009).

From the perspective of accounting, SR, which is also known as TBL or CSR reporting, generally refers to a reporting framework that highlights three important areas, i.e., the economic, environmental and social performance of an organization, in addition to its financial performance (Choudhuri \& Chakraborty, 2009). Global Reporting Initiative (GRI), a prominent organization in the field of sustainability defines SR as the practice of measuring, disclosing, and being accountable to internal and external stakeholders for organizational performance towards the goal of sustainable development (Global Reporting Initiatives, 2011), which is synonymous with other reports used to describe the economic, environmental and social impact, and consistent with TBL and CSR reporting (Global Reporting Initiatives, 2011). Another sustainability leading organization, the Association of Chartered Certified Accountants (ACCA), provides similar definition of SR, i.e., the reporting of the economic, environmental and social impact of organizational performance (ACCA, 2005). From these definitions, it may be concluded that SR denotes the reporting of the economic, environmental and social performance of an organization, which is similar to other related reports by any other name. As a medium of communication between organizations and stakeholders, SR provides information on the sustainability commitments undertaken by firms, which makes the onus of producing SR, much as financial reporting, the responsibility of the corporate boards (Elkington, 2006).

In the Malaysian context, SR is commonly referred to as CSR reporting. Bursa Malaysia (2008) defines CSR as the firms' "commitment to operate in an economically, socially and environmentally sustainable manner whilst balancing the interest of diverse stakeholders". Sustainability or CSR reporting must be disclosed in annual reports of Malaysian listed firms starting from the year 2007 (Ministry of Finance, 2006), where the reporting or disclosure should be made on four focal areas, namely the environment, the workplace, the marketplace and the community (Bursa Malaysia, 2006). Thus, from the various explanations above, sustainability may be defined as the commitments undertaken by the corporate bodies in serving the rights of the stakeholders, which covers the non-financial aspects, such as the environmental and social commitments, with the intention to preserve a sustainable future.

\subsection{The Development of SR in Malaysia}

Numerous studies have been done to determine the level of SR by Malaysian listed firms prior and subsequent to the mandatory requirement (Abdul Rahman, et al., 2010; Haron, et al., 2006; Janggu, et al., 2007; Kasim, 2007; Mohammed, et al., 2009; Mohd Aini \& Sayce, 2010; Muhammad Jamil, et al., 2003; Nik Ahmad, et al., 2003; Saleh, et al., 2010, 2011; Smith, et al., 2007; Teoh \& Thong, 1984; Thompson \& Zakaria, 2004; Zainal, et al., 2013). In the preliminary stage, the SR by Malaysian firms is not as extensive as its real practice 
(Teoh \& Thong, 1984), and shows the sign of poor in quality and low in quantity (Thompson $\&$ Zakaria, 2004). These situations may be associated to several reasons. The most important cause is due to the lack of legislations and regulations on sustainability disclosure (Teoh \& Thong, 1984; Thompson \& Zakaria, 2004). This is also supported by the lack of education on environmental and social responsibility (Ramasamy \& Ting, 2004) during that period. Apart from that, low disclosure is also being caused by the firms' perception that such disclosure does not incur much tangible benefits (Teoh \& Thong, 1984; Thompson \& Zakaria, 2004), such as its positive consequences on financial performance (Ramasamy \& Ting, 2004), and lack of pressure from stakeholders (Thompson \& Zakaria, 2004).

Despite the poor findings in previous studies, Thomson and Zakaria (2004) states that the situation of sustainability awareness and reporting are improving, which is supported by subsequent research which claims that the level of awareness of CSR is high when $83 \%$ of the sampled Malaysian PLCs disclose their social performance (Muniandy \& Barnes, 2010). Saleh, et al. (2010) claims that the level of SR among Malaysian firms are improving gradually between the year 2000 - 2005, while Zainal, et al. (2013), who studied the level of SR in the pre and post period of mandatory disclosure reveals that $100 \%$ of the sampled firms have some SR whether by the extent (sentences count) or quality (CSR index) measurement. However, the previous findings by Muniandy and Barnes (2010), Saleh et al. (2010) and Zainal et al. (2013) have focused on the firms with large size, or to be specific, top listed firms by market capitalization, which might be the reason of the improving sign of SR among the firms. Firms with large sizes tends to have high SR (Amato \& Amato, 2007; Amran \& Devi, 2008; Galbreath, 2011) due to greater public visibility and impact on society (Teoh \& Thong, 1984), thus, they are more likely to engage to sustainability activities as a respond to public pressures (Zainal, et al., 2013).

Past researches also reveals that Malaysian firms tend to give emphasis to human-related SR, which involves the workplace and community themes (Bursa Malaysia, 2008; Haron, et al., 2006; Janggu, et al., 2007; Nik Ahmad, et al., 2003; Saleh, et al., 2010; Thompson \& Zakaria, 2004), and mainly directs to employees training, welfare and benefit and donations and charity activities. Environmental theme has been acknowledged as the least theme to be reported, which may be influenced by industry types. For instance, environmental reporting has been extensively reported by firms in manufacturing, plantation and industrial products sectors, but less by other industries (Bursa Malaysia, 2008; Saleh, et al., 2010) as the activities of the firms in these types of industry may have huge impact to the environment (Amran \& Devi, 2008). However, despite the arguments that plantations industry put priority to environmental theme, Othman and Ameer (2010) reveals that environmental disclosure by firms in plantation industry is still low. Furthermore, Abdul Rahman, et al. (2010) reveals that a firm in finance sector did not have any environmental disclosure in its annual reports for 14 years, indicating that firms in finance industry tend to neglect environmental commitments, which may be due to the perception that their operation do not give huge impact to the environment. Despite the findings by Abdul Rahman, et al. (2010), Singh, et al. (2009) points out that firms in finance industry do have environmental commitments although not as extensive as their social engagements. 
With relations to industry types, even though finance industry do not put forth the environmental engagement (Abdul Rahman, et al., 2010), they tend to have high level of SR as they have the tendency to be more prudent and conscious (Abdul Rashid \& Ibrahim, 2002) besides being heavily regulated and under the purview of Bank Negara (Central Bank) (Amran \& Devi, 2008). Firms that give impact to the environment such as plantation industry also provide a high level of SR (Amran \& Devi, 2008; Saleh, et al., 2010), which is obviously concentrated to environmental commitments as this type of industry deals with issues relating to the environment. The least SR has been found in the hotel industry (Haron, et al., 2006; Saleh, et al., 2010), although earlier research by Muhammad Jamil, et al. (2003) reveals that $100 \%$ of the sampled firms in the hotel industry do have some sort of SR.

\subsection{Commitment to Sustainability: The Role of Malaysian Government}

The commitment of the Malaysian Government to sustainability development can be seen as encouraging. Besides having sustainability agenda supplanted in three out of nine challenges in the Vision 2020, which are the challenges to establish a moral and ethical community, to establish a fully caring culture and to ensure an economically just society, such agenda has also being put forward through the Silver Book, which objective is to promote sustainability awareness and to guide the sustainability activities and implementations among Malaysian Government-Linked Companies (GLCs) and Government-Linked Investment Companies (GLICs) (Putrajaya Committee on GLC High Performance, 2006). In addition, to promote sustainability engagement among corporate firms, the Malaysian Government has imposed a mandatory disclosure of CSR activities among Bursa Malaysia listed firms starting from the year 2007 (Ministry of Finance, 2006). This mandatory requirement has also been gazetted in Bursa Malaysia Listing Requirements under Appendix 9C, Para 29, and firms are encourage to report their CSR activities based on four focal areas, namely the environment, workplace, marketplace and community.

\section{Methodology}

The population of study is the Malaysian listed firms in the year 2011, with the financial year end of 31 December. By using the stratified random sampling technique, 300 firms from 11 industries (excluding the mining industry, which has a zero population during the period under study) are selected as samples. The justification for this action is due to previous findings where it is found that industry types may influence the level of SR. For instance, firms in the manufacturing, plantation and industrial sectors tend to focus more information on the environmental theme of SR as these industries are more involve in environmental impact (Amran \& Devi, 2008; Bursa Malaysia, 2008), while firms in the finance industry may be more positive towards SR as they tend to be more prudent and conscious (Abdul Rashid \& Ibrahim, 2002). As such, by stratifying the listed firms in accordance to their industry before the sampling process will provide a more reliable set of samples. The details of the population and samples for this study are explained in Table 1.

SR activities from the sampled firms' annual reports are the data used for this study. The annual reports are the type of report that is obtainable, as all firms established under the Company's Act 1965 are required to produce such report; and accessible, as this type of 
report may be accessed through Bursa Malaysia website; as such other type of reports such as stand-alone sustainability reports, firms' CSR bulletin and press releases has been ignored from this study. SR activities are captured in four focal areas, which are the environment (EV), workplace (WP), marketplace (MP) and community (CM) themes as outlined by Bursa Malaysia. In order to make the findings more specific, each theme is segregated into different dimensions, where the EV and WP themes contain 8 dimensions each, while the MP and CM themes, both have 7 dimensions. Overall, 30 different dimensions are utilized in this study.

Table 1. Population and Sample

\begin{tabular}{|l|c|c|c|}
\hline \multicolumn{1}{|c|}{ Industry } & Population & Sample & Percentage \\
\hline Construction (CONS) & 23 & 13 & 4.3 \\
\hline Consumer Product (CP) & 69 & 39 & 3.7 \\
\hline Finance (FIN) & 20 & 11 & 0.7 \\
\hline Hotel (HOT) & 4 & 2 & 28.7 \\
\hline Industrial Product (IP) & 154 & 86 & 0.7 \\
\hline Infrastructure (INF) & 4 & 2 & 0.0 \\
\hline Mining (MIN) & 0 & 0 & 4.7 \\
\hline Plantation (PLT) & 25 & 14 & 8.3 \\
\hline Property (PROP) & 44 & 25 & 2.0 \\
\hline Real Estate Investment Trust (REIT) & 11 & 6 & 10.7 \\
\hline Technology (TECH) & 58 & 32 & 23.3 \\
\hline Trading and Services (TS) & 126 & 70 & 100.0 \\
\hline Total & 538 & 300 & \\
\hline
\end{tabular}

In measuring the SR activities, this study implements 2 types of measurements, which are the quality of reporting (QUAL) and the extent of reporting (EXT). QUAL seeks to evaluate the quality of disclosures by using the quality index, where the aim is to distinguish between the poor and excellent disclosure of items (Hooks \& van Staden, 2011). For the purpose of this study, a 4-point index with the scale of $0-3$, which has been used in previous research (Hoq, Saleh, Zubayer, \& Mahmud, 2010; Saleh, et al., 2010, 2011; Zainal, et al., 2013) is utilized. A score of 0 denotes a non-disclosure, 1 for general qualitative disclosure, 2 for qualitative disclosure with specific explanations, and 3 for quantitative data. Accordingly, the quality index is derived by computing the ratio of the total scores to the maximum score attainable, with the following formula:

$$
\text { QUALSR }_{\mathrm{j}}=\frac{\sum_{t=1}^{n j} X_{\mathrm{ij}}}{\mathrm{n}_{\mathrm{j}}}
$$


where

$$
\begin{aligned}
& \text { QUALSR }_{\mathrm{j}}=\quad \text { quality of CSR for } j \text { th firm. } \\
& \mathrm{n}_{\mathrm{j}}=\quad \begin{array}{l}
\text { total number of items estimated for } j \text { th firm, with maximum score } \\
\text { assigned. }
\end{array} \\
& \mathrm{X}_{\mathrm{ij}} \quad \begin{array}{l}
\text { the score of } 3 \text { for the } i \text { th item if quantitative data is disclosed, the score of } \\
2 \text { for the } i \text { th item if qualitative data with specific explanation is disclosed, } \\
\text { the score of } 1 \text { for the ith item if general qualitative data is disclosed and } \\
\text { the score of } 0 \text { for the } i \text { th item if there is no disclosure. }
\end{array}
\end{aligned}
$$

By utilizing this formula, firms that achieve maximum score for each theme may have the maximum index score of 1 .

While QUAL aims to distinguish between the poor and excellent disclosure of items (Hooks \& van Staden, 2011), the extent of reporting (EXT) seeks to evaluate the disclosure in term of "how many", thus this study adapts the number of sentences in determining the quantity of SR. This method is justified as a more reliable method; as a complete sentence makes better sense compared to counting the words (Milne \& Adler, 1999). However, counting for sentences alone is not enough as this may omit information that may be generated from tables, pictures, graphs and charts. However, these flaws are corrected by taking 15 words in a table or the captions on the graphs, charts and pictures as equal to one sentence (Hooks \& van Staden, 2011).

\section{Findings}

The Malaysian listed firms are required to disclose their SR activities in the annual report starting from the year 2007 (Ministry of Finance, 2006), where this requirement has been gazetted in Bursa Malaysia Listing Requirements under Appendix 9C, Para 29. As the mandatory disclosure being imposed, it is being expected that $100 \%$ of the sampled firms will have such reporting. However, contrary to the expectation, several firms do not comply with this requirement, where 9 firms fail to do so, comprises of 1 firm in consumer product (CP) industry, 5 firms in industrial product (IP) industry, 2 firms in real estate investment trust (REIT) industry and 1 firm in the trading and services (TS) industry. Although the percentage is small, which is only $3 \%$, this situation explains that despite having the regulation on the SR activities mandatory disclosure, still there are firms which do not take the matters of the disclosure seriously. Moreover, when across-industry analysis is done, the result reveals that $33 \%$ of firms in REIT industry do not incorporate SR in their annual report. Table 2 depicts the result of SR availability in the annual reports of the sampled firms. 
Table 2. Sustainability Reporting Availability

\begin{tabular}{|c|c|c|c|c|c|}
\hline & \multicolumn{2}{|l|}{ Frequency } & \multicolumn{3}{|c|}{ Percent } \\
\hline Not Available & \multicolumn{2}{|l|}{9} & \multicolumn{3}{|c|}{3.0} \\
\hline Available & \multicolumn{2}{|l|}{291} & \multicolumn{3}{|c|}{97} \\
\hline Total & \multicolumn{2}{|l|}{300} & \multicolumn{3}{|c|}{100.0} \\
\hline & \multicolumn{5}{|c|}{ Availability } \\
\hline Industry & Samples & Available & $\%$ & Not Available & $\%$ \\
\hline Construction (CONS) & 13 & 13 & 100 & 0 & 0 \\
\hline Consumer Product (CP) & 39 & 38 & 97 & 1 & 3 \\
\hline Finance (FIN) & 11 & 11 & 100 & 0 & 0 \\
\hline Hotel (HOT) & 2 & 2 & 100 & 0 & 0 \\
\hline Industrial Product (IP) & 86 & 81 & 94 & 5 & 6 \\
\hline Infrastructure (INF) & 2 & 2 & 100 & 0 & 0 \\
\hline Mining (MIN) & 0 & 0 & 100 & 0 & 0 \\
\hline Plantation (PLT) & 14 & 14 & 100 & 0 & 0 \\
\hline Property (PROP) & 25 & 25 & 100 & 0 & 0 \\
\hline Real Estate Investment Trust (REIT) & 6 & 4 & 67 & 2 & 33 \\
\hline Technology (TECH) & 32 & 32 & 100 & 0 & 0 \\
\hline Trading and Services (TS) & 70 & 69 & 99 & 1 & 1 \\
\hline Total & 300 & 491 & & 9 & \\
\hline
\end{tabular}

In determining the quality and extent of disclosure (Refer to Table 3. Descriptive Statistics), the results indicate that the minimum score for QUAL and EXT is 0, which may be explained by 3 situations. Firstly, it is due to the totally lack of SR disclosure by respective firms in the year under study. Secondly, the SR disclosure exists; however, the disclosure is too general to be interpreted in accordance to the four specific themes and thirty dimensions. For instance, one of the firms states that "The Group will continuously explore, identify and act on social issues which are relevant" - BLD Plantations Berhad, which do not give any picture as to which theme or dimension that this disclosure should be assigned to. Thirdly, the SR disclosure exists, however, the disclosure points out that no such activities has been undertaken for the particular years, for instance, "We have not been involved or undertaken any corporate social responsibility activities or practices..." - Amanah Harta Tanah PNB or "During the financial year, no activity was conducted by the Group in relation to the Corporate Social Responsibility" - Naim Indah Corporation Berhad.

The maximum score for the quality index (QUAL) was 0.84 while for EXT, the maximum sentences disclosed was 1,055.4 sentences. Overall, the mean for QUAL amounted to 0.1450, while the mean for EXT was 42.418 sentences. The findings indicates that in terms of quality, the disclosure may be considered as weak in quality as the average quality index score is only 0.1450 points, compared to the overall quality score of 1.00 points. However, in terms of the extent of disclosure, the sampled firms show an increasing number of sentences disclosed, 
with 42.418 sentences on average, compared to only 20.14 sentences in the year 2000 annual reports (Nik Ahmad, et al., 2003).

By separate themes, the mean for quality index, QUAL for EV theme amounted to 0.1197, WP with 0.1617, MP with 0.0946 and CM with 0.2052. The mean EXT score for EV theme showed 8.354 sentences, WP with 14.402 sentences, MP with 7.723 sentences, while CM theme with 11.938 sentences. From these findings we may observe a few points. Firstly, after about 5 years of mandatory CSR disclosure by Malaysian listed firms, the themes that are most disclosed whether by quality or extent are the workplace and community themes. However, by comparing between the two measurements, the WP theme marks the highest extent of reporting but came second in the quality reporting, and vice versa to CM theme, which marks the best in quality and second in the extent. For the other two themes however, the findings indicate that EV theme and MP theme marks the third and last place in both measurements of CSR activities disclosure. These findings explain that Malaysian firms put emphasis on the "people" related SR activities, which may be viewed in both WP and CM themes, but less on the EV and MP themes, and is more likely to be the same with previous research prior to the mandatory years of SR disclosure (Nik Ahmad, et al., 2003; Thompson \& Zakaria, 2004; Haron, et al., 2006; Janggu, Joseph, \& Madi, 2007; Bursa Malaysia, 2008).

Although there is some reporting for each theme, the findings also reveal that the quality of reporting may be considered as poor. This may be explained by the maximum score which may be achieved by each firm in accordance to the separate themes. For instance, the maximum quality index score for each theme which may be achieved is 1, but the sampled firms just manage to achieve 0.1197 for EV, 0.1617 for WP, 0.0946 for MP and 0.2052 for $\mathrm{CM}$, which shows that the firms under study may only disclose CSR activities in a small number of dimensions or may be due to the disclosure of general statements for each dimensions, which results in the low quality index score.

Further analysis is done to determine the quality and extent of SR according to specific dimensions (Refer Table 4). The findings reveal that there is not much difference in results using the two measurements. For instance, in the EV theme, the most disclosed dimension, whether in term of quality or extent are the environmental conservation, environmental campaign and effective usage of energy and resources. The highest point in both measurements by the environmental conservation and environmental campaign dimensions depicts that firms prefer more or inclined to the outside CSR activities, such as tree planting, river cleaning and also involving themselves with the communities such as giving environmental talk to the communities and participating in the communities' earth and environmental campaign such as the "Earth Hour".

In the WP theme, the most reported dimensions are the employee welfare and benefit, employee training and education and employee safety and health, in both measurements. Employee training is positively related to organizational commitments (Brammer, Millington, \& Rayton, 2007), which explains why firms put priority to training and education, thus securing their best talents, which in the end, may give impact to firms' performance. By securing the employees' welfare, benefits, safety and health, firms may also secure their 
subordinates from moving to other companies, which will be a waste in term of staff turnover, as this may involve losing skilled employees to other companies.

Table 3. Descriptive Statistics

\begin{tabular}{|c|c|c|c|c|c|}
\hline \multicolumn{6}{|c|}{ Quality of Reporting (QUAL) } \\
\hline & Minimum & Maximum & Sum & Mean & Std. Deviation \\
\hline EV & 0.0 & 0.83 & 35.92 & 0.1197 & 0.1679 \\
\hline WP & 0.0 & 0.83 & 48.50 & 0.1617 & 0.1733 \\
\hline MP & 0.0 & 0.86 & 28.38 & 0.0946 & 0.1540 \\
\hline $\mathrm{CM}$ & 0.0 & 0.95 & 61.57 & 0.2052 & 0.2065 \\
\hline Total QUAL & 0.0 & 0.84 & 43.50 & 0.1450 & 0.1550 \\
\hline \multicolumn{6}{|c|}{ Extent of Reporting (EXT) } \\
\hline & Minimum & Maximum & Sum & Mean & Std. Deviation \\
\hline EV & 0.0 & 221.8 & 2506.1 & 8.354 & 22.7810 \\
\hline WP & 0.0 & 274.2 & 4320.7 & 14.402 & 34.4444 \\
\hline MP & 0.0 & 449.7 & 2317.0 & 7.723 & 30.6514 \\
\hline $\mathrm{CM}$ & 0.0 & 147.2 & 3581.5 & 11.938 & 21.3881 \\
\hline Total EXT & 0.0 & $1,055.4$ & $12,725.3$ & 42.418 & 97.5773 \\
\hline \multicolumn{6}{|c|}{$\mathrm{EV}=$ Environment $\quad \mathrm{WP}=$ Workplace } \\
\hline \multicolumn{2}{|c|}{ QUAL = Quality of Reporting } & \multicolumn{4}{|c|}{ EXT $=$ Extent of Reporting } \\
\hline
\end{tabular}

The same situation goes with the CM theme, where both measurements marks the charity programs, donations programs and training, education and scholarship dimensions to be the best reported both in term of quality and extent. The findings indicate that firms tend to be inclined to the activities that involved the act of 'giving' to the communities compared to other CSR activities such as providing job opportunities to the local communities.

In the MP theme, the result shows that the product and service quality dimension portrays to be the best of quality and extent of SR. The good disclosure for product and service quality dimension may be due to the impact that it might bring to the performance of the firm. If a firm manages to give good reputation for its products or services, the firm may achieve a long-term superior performance. Therefore, firms tend to give priority to their product and services quality compared to other dimensions in the MP theme. Firms also put priority to their customer services, which may be observed through the second highest disclosure in the number of sentences, as customer services, particularly the "after-sales services" may influence the customers or consumers to come back and do business again with the respective firms, which in the long-run, will also improve firms' performance. A more interesting finding from this study is that firms were interested in stakeholder engagement, where this dimension marks the second best disclosure in quality. Again, this shows that firms nowadays are concerned to open their door to the stakeholders, as they are more open to accepting visits whether from the government officials, students and NGOs, and at the same time conduct meetings with the stakeholders to understand their needs and expectations. Another interesting point is that firms tend to disclose more on the certifications and award achievements related to the MP theme. This may be due to the reputation which may be 
gained through such disclosure, as stakeholders may perceive that firms which are high achievers in respective areas may provide the best of product or services.

Further analysis is to determine if the quality and extent of CSR varies according to industry type. By referring to Table 5, the findings of this study revealed that the firms in infrastructure industry (INF) marked the highest in QUAL of SR with the quality index mean of 0.489 , followed by finance industry (FIN) with the mean score of 0.306 and Plantation industry (PLT) with 0.256 . The poorest disclosure in QUAL is pointed to the firms in hotel industry (HOT) with the quality index mean score of 0.050 .

With regards to the extent of CSR, the result indicated the same outcome as in the quality of reporting, where the INF industry seemed to dominate the extent of reporting, with the mean of 544.2 sentences. The second in line are the firms in the FIN industry with the mean of 135.05 sentences in 2011, followed by PLT industry with the mean of 101.08 sentences. As for the lowest SR quantity, firms in the HOT industry marks the weakest with the mean of only 6.5 sentences.

By separate themes, in term of quality of reporting (QUAL), INF industry depicts the highest quality index score for 3 out of 4 themes covered in this study, which are the EV, WP and the MP themes, and becomes second in the MP theme after the FIN industry. PLT industry marks the second place with good quality and high in quantity of SR for EV theme, and third place in the other three themes (WP, MP and CM), while FIN industry secures the position of firms that disclose the most excellent quality of reporting in the CM theme, second in WP and MP themes, and third in the EV theme. In term of the extent of reporting (EXT), firms in INF industry depict the highest extent of SR in all 4 themes, PLT industry marks the second place EV theme, while in the other three themes, FIN industry performs better quality and extent of CSR compared to PLT. The firms in HOT industry disclose the poorest level in quality and extent of SR in the EV and WP themes, plus second poorest quality in MP theme and second poorest extent in MP theme. Firms in IP industry marked the poorest in quality for CM theme, while REIT industry marked the lowest extent of SR for MP theme.

\section{Discussions and Conclusions, Limitations and Future Research}

The first objective of this study is to examine the availability of SR among Malaysian listed firms. As the mandatory disclosure of SR being imposed on Malaysian Listed Firms in their annual reports, it is being expected that all firms under study will exhibit some sort of SR. The results however indicate that despite having mandatory policy on such disclosure, 3\% (9 firms) of the sampled firms do not have SR in their annual report, which consists of 5 firms in the industrial product, 2 firms in the REIT and 1 firm in both consumer product and trading and services industry. The interesting point is that $33 \%$ of firms in the REIT industry do not incorporate SR in the annual report. The situation might be due to the low level of holdings by institutional investors in the REIT industry firms (Newell, Ting Kien, \& Acheampong, 2002), as previous studies identified that the presence of institutional investors in a firm's shareholding structure may enhance SR (Amran \& Devi, 2008; Coffey \& Fryxell, 1991; Oh \& Chang, 2011; Said, Zainuddin, \& Haron, 2009). 
Table 4. Descriptive Statistics according to Themes and Dimensions

\begin{tabular}{|c|c|c|c|c|c|c|c|c|c|c|}
\hline & \multicolumn{5}{|c|}{ QUAL } & \multicolumn{5}{|c|}{ EXT } \\
\hline & Min & Max & Sum & Mean & SD & Min & Max & Sum & Mean & SD \\
\hline \multicolumn{11}{|c|}{ ENVIRONMENT (EV) } \\
\hline Waste Management and Disposal & 0.00 & 1.00 & 34.67 & 0.116 & 0.242 & 0.00 & 24.7 & 227.4 & 0.758 & 2.614 \\
\hline Pollution and Emission Control & 0.00 & 1.00 & 27.33 & 0.091 & 0.233 & 0.00 & 56.3 & 210.3 & 0.701 & 3.726 \\
\hline Reusing and Recycling & 0.00 & 1.00 & 33.67 & 0.112 & 0.227 & 0.00 & 11.0 & 182.5 & 0.608 & 1.503 \\
\hline Effective Usage of Energy and Resources & 0.00 & 1.00 & 39.00 & 0.130 & 0.263 & 0.00 & 55.4 & 421.6 & 1.405 & 5.186 \\
\hline Prevention and Reparation Program & 0.00 & 1.00 & 22.67 & 0.076 & 0.213 & 0.00 & 42.3 & 263.0 & 0.877 & 3.973 \\
\hline Environmental Conservation & 0.00 & 1.00 & 59.33 & 0.198 & 0.289 & 0.00 & 156.1 & 688.0 & 2.293 & 10.036 \\
\hline Environmental Campaign & 0.00 & 1.00 & 40.00 & 0.133 & 0.281 & 0.00 & 45.0 & 335.8 & 1.119 & 4.138 \\
\hline Certification and Awards Achievement & 0.00 & 1.00 & 30.67 & 0.102 & 0.245 & 0.00 & 18.0 & 177.5 & 0.592 & 1.999 \\
\hline TOTAL ENV & 0.00 & 0.83 & 35.92 & 0.120 & 0.168 & 0.00 & 221.8 & $2,506.1$ & 8.354 & 22.781 \\
\hline \multicolumn{11}{|c|}{ WORKPLACE (WP) } \\
\hline Employee Training and Education & 0.00 & 1.00 & 86.00 & 0.287 & 0.318 & 0.00 & 73.3 & 932.0 & 3.107 & 7.6476 \\
\hline Employee Health and Safety & 0.00 & 1.00 & 79.33 & 0.264 & 0.318 & 0.00 & 110.8 & 1086.0 & 3.620 & 10.570 \\
\hline Employee Welfare and Benefits & 0.00 & 1.00 & 93.33 & 0.311 & 0.342 & 0.00 & 67.3 & 1101.3 & 3.671 & 8.512 \\
\hline Share Options for Employees & 0.00 & 1.00 & 24.33 & 0.081 & 0.269 & 0.00 & 18.6 & 119.3 & 0.398 & 1.687 \\
\hline Employee Development and Recognition & 0.00 & 1.00 & 51.00 & 0.170 & 0.307 & 0.00 & 66.1 & 602.1 & 2.007 & 7.229 \\
\hline Freedom of Voice, Communication Channel & 0.00 & 1.00 & 24.00 & 0.080 & 0.222 & 0.00 & 24.3 & 194.7 & 0.649 & 2.577 \\
\hline Discrimination, Child Labour and Corruption & 0.00 & 1.00 & 15.33 & 0.051 & 0.184 & 0.00 & 44.3 & 180.8 & 0.603 & 3.656 \\
\hline Certification and Awards Achievement & 0.00 & 1.00 & 14.67 & 0.049 & 0.170 & 0.00 & 26.3 & 104.5 & 0.348 & 2.038 \\
\hline TOTAL WP & 0.00 & 0.83 & 48.50 & 0.162 & 0.173 & 0.00 & 274.2 & $4,320.7$ & 14.402 & 34.444 \\
\hline \multicolumn{11}{|c|}{ MARKETPLACE (MP) } \\
\hline Product Development & 0.00 & 1.00 & 22.33 & 0.074 & 0.223 & 0.00 & 53.1 & 253.8 & 0.846 & 4.045 \\
\hline Product Safety & 0.00 & 1.00 & 6.33 & 0.021 & 0.119 & 0.00 & 61.0 & 96.8 & 0.323 & 3.697 \\
\hline Product and Service Quality & 0.00 & 1.00 & 48.00 & 0.160 & 0.289 & 0.00 & 95.4 & 528.3 & 1.761 & 6.605 \\
\hline Customer Services & 0.00 & 1.00 & 18.67 & 0.062 & 0.204 & 0.00 & 153.8 & 513.7 & 1.712 & 12.499 \\
\hline Stakeholder Engagement & 0.00 & 1.00 & 45.67 & 0.152 & 0.270 & 0.00 & 45.8 & 415.4 & 1.385 & 4.176 \\
\hline Certification and Awards Achievement & 0.00 & 1.00 & 41.00 & 0.137 & 0.273 & 0.00 & 38.7 & 424.9 & 1.416 & 5.207 \\
\hline Customer and Supplier Training & 0.00 & 1.00 & 16.67 & 0.056 & 0.192 & 0.00 & 9.0 & 84.1 & 0.280 & 1.149 \\
\hline TOTAL MP & 0.00 & 0.86 & 28.38 & 0.095 & 0.154 & 0.00 & 449.7 & $2,317.0$ & 7.723 & 30.651 \\
\hline \multicolumn{11}{|c|}{ COMMUNITY (CM) } \\
\hline Donations programs & 0.00 & 1.00 & 98.33 & 0.328 & 0.390 & 0.00 & 50.0 & 623.7 & 2.079 & 5.047 \\
\hline Job Opportunity & 0.00 & 1.00 & 19.33 & 0.064 & 0.203 & 0.00 & 39.8 & 132.2 & 0.441 & 2.565 \\
\hline Public Projects & 0.00 & 1.00 & 66.33 & 0.221 & 0.3653 & 0.00 & 34.8 & 580.2 & 1.934 & 4.935 \\
\hline Training, Education and Scholarships & 0.00 & 1.00 & 80.33 & 0.268 & 0.380 & 0.00 & 83.2 & 751.6 & 2.505 & 7.072 \\
\hline Charity programs & 0.00 & 1.00 & 123.00 & 0.410 & 0.389 & 0.00 & 46.1 & $1,201.8$ & 4.006 & 7.062 \\
\hline Certification and Awards Achievement & 0.00 & 1.00 & 9.67 & 0.032 & 0.150 & 0.00 & 24.0 & 65.1 & 0.217 & 1.605 \\
\hline Sports and Cultural Activities & 0.00 & 1.00 & 34.00 & 0.113 & 0.282 & 0.00 & 32.0 & 226.9 & 0.756 & 2.813 \\
\hline TOTAL CM & 0.00 & 0.95 & 61.57 & 0.205 & 0.207 & 0.00 & 147.2 & $3,581.5$ & 11.938 & 21.388 \\
\hline GRAND TOTAL & 0.00 & 0.84 & 43.50 & 0.145 & 0.155 & 0.00 & 1,055 & 12,725 & 42.418 & 97.577 \\
\hline
\end{tabular}


Table 5. QUAL and EXT across Industry

\begin{tabular}{|c|c|c|c|c|c|c|c|c|c|c|c|c|}
\hline \multirow[b]{2}{*}{ Industry } & \multirow[b]{2}{*}{$\mathrm{N}$} & & \multicolumn{5}{|c|}{ QUAL } & \multicolumn{5}{|c|}{ EXT } \\
\hline & & & EV & WP & MP & $\mathrm{CM}$ & $\begin{array}{l}\text { QUAL } \\
\text { Total }\end{array}$ & EV & WP & MP & $\mathrm{CM}$ & $\begin{array}{l}\text { EXT } \\
\text { Total }\end{array}$ \\
\hline \multirow{2}{*}{$\begin{array}{l}\text { Construction } \\
\text { (CONS) }\end{array}$} & \multirow{2}{*}{13} & Mean & .093 & .170 & 0.070 & 0.194 & .132 & 5.231 & 8.892 & 3.100 & 10.654 & 27.877 \\
\hline & & $\mathrm{SD}$ & .102 & .134 & 0.114 & 0.149 & .114 & 9.816 & 6.814 & 6.402 & 19.195 & 39.293 \\
\hline \multirow{2}{*}{$\begin{array}{l}\text { Consumer } \\
\text { Product (CP) }\end{array}$} & \multirow{2}{*}{39} & Mean & .150 & .173 & 0.120 & 0.238 & .170 & 9.767 & 13.321 & 7.618 & 14.028 & 44.733 \\
\hline & & SD & .162 & .177 & 0.176 & 0.197 & .149 & 19.772 & 33.318 & 16.383 & 20.940 & 84.626 \\
\hline \multirow{2}{*}{ Finance (FIN) } & \multirow{2}{*}{11} & Mean & .182 & .341 & 0.251 & 0.463 & .306 & 12.882 & 53.291 & 29.782 & 39.091 & 135.045 \\
\hline & & SD & .178 & .231 & 0.246 & 0.239 & .197 & 16.773 & 73.251 & 44.931 & 38.601 & 162.495 \\
\hline \multirow{2}{*}{ Hotel (HOT) } & \multirow{2}{*}{2} & Mean & .021 & .021 & 0.024 & 0.142 & .050 & .500 & 1.000 & 1.500 & 3.500 & 6.500 \\
\hline & & SD & .029 & .029 & 0.034 & 0.067 & .039 & .707 & 1.414 & 2.121 & .707 & 4.950 \\
\hline \multirow{2}{*}{$\begin{array}{l}\text { Industrial } \\
\text { Product (IP) }\end{array}$} & \multirow{2}{*}{86} & Mean & .096 & .120 & 0.049 & 0.124 & .098 & 4.316 & 6.319 & 1.814 & 4.564 & 17.013 \\
\hline & & SD & .135 & .116 & 0.102 & 0.147 & .107 & 9.568 & 10.964 & 4.345 & 7.437 & 29.290 \\
\hline \multirow{2}{*}{$\begin{array}{l}\text { Infrastructure } \\
\text { (INF) }\end{array}$} & \multirow{2}{*}{2} & Mean & .521 & .500 & 0.571 & 0.357 & .489 & 109.650 & 139.600 & 229.850 & 65.100 & 544.200 \\
\hline & & SD & .383 & .354 & 0.404 & 0.236 & .346 & 140.926 & 190.353 & 310.915 & 80.752 & 722.946 \\
\hline \multirow{2}{*}{$\begin{array}{l}\text { Plantation } \\
\text { (PLT) }\end{array}$} & \multirow{2}{*}{14} & Mean & .260 & .289 & 0.143 & 0.330 & .256 & 33.721 & 37.843 & 11.671 & 17.843 & 101.079 \\
\hline & & SD & .243 & .233 & 0.188 & 0.226 & .207 & 60.737 & 51.936 & 19.792 & 21.951 & 135.134 \\
\hline \multirow{2}{*}{$\begin{array}{l}\text { Property } \\
\text { (PROP) }\end{array}$} & \multirow{2}{*}{25} & Mean & .085 & .125 & 0.084 & 0.276 & .140 & 5.200 & 7.460 & 4.636 & 15.020 & 32.316 \\
\hline & & SD & .130 & .165 & 0.136 & 0.253 & .154 & 12.895 & 11.476 & 11.119 & 22.688 & 50.643 \\
\hline \multirow{2}{*}{$\begin{array}{l}\text { Real Est. Inv. } \\
\text { Trust (REIT) }\end{array}$} & \multirow{2}{*}{6} & Mean & .083 & .063 & 0.024 & 0.159 & .082 & 3.167 & 3.917 & .500 & 7.250 & 14.833 \\
\hline & & SD & .204 & .153 & 0.040 & 0.194 & .134 & 7.757 & 9.594 & .837 & 10.490 & 26.969 \\
\hline \multirow{2}{*}{$\begin{array}{l}\text { Technology } \\
\text { (TECH) }\end{array}$} & \multirow{2}{*}{32} & Mean & .065 & .135 & 0.103 & 0.158 & .114 & 2.312 & 9.522 & 4.878 & 6.231 & 22.944 \\
\hline & & SD & .078 & .159 & 0.131 & 0.160 & .111 & 3.345 & 18.036 & 7.911 & 9.722 & 34.217 \\
\hline \multirow{2}{*}{$\begin{array}{l}\text { Trading and } \\
\text { Services (TS) }\end{array}$} & \multirow{2}{*}{70} & Mean & .132 & .180 & 0.101 & 0.221 & .158 & 8.984 & 17.576 & 8.499 & 15.257 & 50.316 \\
\hline & & SD & .202 & .185 & 0.154 & 0.225 & .174 & 18.265 & 37.627 & 21.966 & 25.828 & 95.318 \\
\hline \multirow{2}{*}{ Total } & \multirow{2}{*}{300} & Mean & .120 & .162 & 0.095 & 0.205 & .145 & 8.354 & 14.402 & 7.723 & 11.938 & 42.418 \\
\hline & & SD & .168 & .173 & 0.154 & 0.206 & .155 & 22.781 & 34.444 & 30.651 & 21.388 & 97.577 \\
\hline
\end{tabular}

The second objective of this study is to examine the extent and the quality of SR among Malaysian listed firms. In term of quality, the results indicate that the quality SR by Malaysian listed firms are still low with the quality index score of only 0.1450 compared to the overall index score of 1 . However, in term of extent, the sampled firms scored a mean of 42.418 sentences. Therefore, we may conclude that Malaysian firms have the tendency to report, but, the content is rather limited to general information and qualitative information.

With relations to the themes and dimensions reported, the results indicate that human-related SR which consists of the workplace and community themes, are the most to be reported, whether measured by extent or by the quality of reporting. The results are more or less the same with what was found in previous studies, where firms put more effort to engage in sustainability activities involving both themes (Bursa Malaysia, 2008; Haron, et al., 2006; Janggu, et al., 2007; Nik Ahmad, et al., 2003; Saleh, et al., 2010; Thompson \& Zakaria, 
2004). In the workplace theme, firms put priority to the employee welfare and benefits, followed by employee training and education and employee health and safety, while for community theme, charity programs become the most popular type of engagement, followed by donations program and training, education and scholarships. Firms also show emphasis on the product and service quality dimension in the marketplace theme, and environment conservation dimension in the environment theme.

The across-industry analysis reveals that firms in the infrastructure industry dominates SR the extent and quality of reporting in total, while firms in the hotel industry marks the poorest quality and lowest extent of SR. By separate themes, the firms in this industry performs highest in quantity in each theme and marks the most excellent of quality in environment, workplace and marketplace themes. These finding indicate that SR by firms in the infrastructure industry shows an improvement, as in previous studies by Saleh (2009), conclude that infrastructure industry marked the second highest after plantation industry with relation to the quality of SR. The improvement in the quality and extent of SR by the firms in the infrastructure industry may be due its nature of greater exposure to risks (Amran, Rosli, \& Hassan, 2009), as such, more information may be demanded by the stakeholders, which may explain the act of disclosing the SR activities. Firms in the finance industry depicts the second highest score in both quality and extent measures for total SR, highest in the quality of CM theme and in second place for quality and extent of WP and MP themes and extent of CM. This findings are consistent to previous studies, where prudent and conscious act by firms in finance industry (Abdul Rashid \& Ibrahim, 2002) and being heavily regulated and under the purview of Bank Negara (Central Bank) (Amran \& Devi, 2008) seems the logical explanation for high level of SR. Firms in the plantation industry, which receives the third highest score for quality and extent of SR marks the second highest score for EV theme by both measurements. This result indicates that firms in the plantation industry concentrate more to environmental theme of SR, which may be explained as their nature of activities which give great impact to the environment (Amran \& Devi, 2008).

The study is not without limitation. As the objective of this study is to examine the availability of SR in the annual reports subsequent to the mandatory disclosure, other types of disclosure such as stand-alone sustainability reports have been neglected. As such, future research may consider incorporating such reports to gauge the level of SR among Malaysian firms. The findings from this study have also indicated that the lowest level of SR in both extent and quality is among the firms in the hotel industry. Although this finding is consistent to previous research (Haron, et al., 2006; Saleh, et al., 2010), future research may consider to fill the gap as why this type of industry depicts the lowest of quality and extent of SR although their operation might give impact to the environment in terms of waste, energy and resources. Furthermore, as services provider, firms in hotel industry are closely connected to the clients, as such, it is expected that they might have good engagement to environment and marketplace sustainability activities. 


\section{References}

Abdul Rahman, A., Md Hashim, M. F. A., \& Abu Bakar, F. (2010). Corporate Social Reporting: A Preliminary Study of Bank Islam Malaysia Berhad (BIMB). Issues in Social \& Environmental Accounting, 4(1), 18-39.

Abdul Rashid, M. Z., \& Ibrahim, S. (2002). Executive and Management Attitudes towards Corporate Social Responsibility in Malaysia. Corporate Governance, 2(4), 10-16. http://dx.doi.org/10.1108/14720700210447641.

ACCA. (2005). Sustainability Reporting Guidelines for Malaysian Companies.

Amato, L., \& Amato, C. (2007). The Effects of Firm Size and Industry on Corporate Giving. Journal of Business Ethics, 72(3), 229-241. http://dx.doi.org/10.1007/s10551-006-9167-5.

Amran, A., \& Devi, S. S. (2007). Corporate Social Reporting in Malaysia: A Political Theory Perspective. Malaysian Accounting Review, 6(1), 19-44.

Amran, A., \& Devi, S. S. (2008). The Impact of Government and Foreign Affiliate influence on Corporate Social Reporting The Case of Malaysia. Managerial Auditing Journal, 23(4), 386-404. http://dx.doi.org/10.1108/02686900810864327.

Amran, A., Rosli, A. M., \& Hassan, C. H. M. (2009). Risk Reporting: An Exploratory Study on Risk Management Disclosure in Malaysian Annual Reports. Managerial Auditing Journal, 24(1), 39-57. http://dx.doi.org/10.1108/02686900910919893.

Brammer, S., Millington, A., \& Rayton, B. (2007). The Contribution of Corporate Social Responsibility to Organizational Commitment. International Journal of Human Resource Management, 18(10), 1701-1719. http://dx.doi.org/10.1080/09585190701570866.

Bursa Malaysia. (2006). Bursa Malaysia's CSR Frameworks for Malaysian PLCs. Retrieved from

http://www.bursamalaysia.com/website/bm/about_us/the_organisation/csr/downloads/csr_fra mework_slides.pdf.

Bursa Malaysia. (2008). CSR 2007 Status Report.

Carroll, A. B. (1991). The Pyramid of Corporate Social Responsibility: Toward the Moral Management of Organizational Stakeholders. Business Horizons, 34, 39-48.

Choudhuri, A., \& Chakraborty, J. (2009). An Insight into Sustainability Reporting. ICFAI Journal of Management Research, 8(4), 46-53.

Christensen, L. J., Peirce, E., Hartman, L., Hoffman, W., \& Carrier, J. (2007). Ethics, CSR, and Sustainability Education in the Financial Times Top 50 Global Business Schools: Baseline Data and Future Research Directions. Journal of Business Ethics, 73, 347-368. http://dx.doi.org/10.1007/s10551-006-9211-5. 
Coffey, B. S., \& Fryxell, G. E. (1991). Institutional Ownership of Stock and Dimensions of Corporate Social Performance: An Empirical Examination. Journal of Business Ethics, 10, 437-444.

Elkington, J. (1997). Cannibals With Forks: the Triple Bottom Line of 21 st Century Business. Oxford: Capstone.

Elkington, J. (2006). Governance for Sustainability. Corporate Governance: An International Review, 14(6), 522-529. http://dx.doi.org/10.1111/j.1467-8683.2006.00527.x.

Galbreath, J. (2011). Are there Gender-related Influences on Corporate Sustainability? A Study of Women on Boards of Directors. Journal of Management \& Organization, 17, 17-38.

Global Reporting Initiatives. (2011). Sustainability Reporting Guidelines Version 3.1.

Haniffa, R. M., \& Cooke, T. E. (2005). The Impact of Culture and Governance on Corporate Social Reporting. Journal of Accounting and Public Policy, 24(5), 391-430. http://dx.doi.org/10.1016/j.jaccpubpol.2005.06.001.

Haron, H., Yahya, S., Manasseh, S., \& Ismail, I. (2006). Level of Corporate Social Disclosure in Malaysia. Malaysian Accounting Review, 5(1), 159-184.

Hooks, J., \& van Staden, C. J. (2011). Evaluating Environmental Disclosures: The Relationship between Quality and Extent Measures. The British Accounting Review, 43(3), 200-213. http://dx.doi.org/10.1016/j.bar.2011.06.005.

Hoq, M. Z., Saleh, M., Zubayer, M., \& Mahmud, K. T. (2010). The Effect of CSR Disclosure on Institutional Ownership. Pakistan Journal of Commerce \& Social Sciences, 4(1), 22-39.

Janggu, T., Joseph, C., \& Madi, N. (2007). The Current State of Corporate Social Responsibility Among Industrial Companies in Malaysia. Social Responsibility Journal, 3(3), 9-18.

Kasim, A. (2007). Corporate Environmentalism in the Hotel Sector: Evidence of Drivers and Barriers in Penang, Malaysia. Journal of Sustainable Tourism, 15(6), 680-699. http://dx.doi.org/10.2167/jost575.0.

Lu, J. Y., \& Castka, P. (2009). Corporate Social Responsibility in Malaysia - Experts' Views and Perspectives. Corporate Social Responsibility \& Environmental Management, 16(3), 146-154. http://dx.doi.org/10.1002/csr.184.

Milne, M. J., \& Adler, R. W. (1999). Exploring the Reliability of Social and Environmental Disclosures Content Analysis. Accounting, Auditing \& Accountability Journal, 12(2), 237.

Ministry of Finance. (2006). The Malaysian 2007 Budget Speech. Retrieved from http://www.treasury.gov.my/pdf/budget/bs07.pdf.

Mohammed, R., Alwi, K., \& Muhammad Jamil, C. Z. (2009). Sustainability Disclosure among Malaysian Shari'ah-Compliant listed Companies: Web Reporting. Issues in Social \& Environmental Accounting, 3(2), 160-179. 
Mohd Aini, A., \& Sayce, S. (2010). Disclosing Environmental and Sustainability Practices and Initiatives in the Annual Reporting Process of Property Investors: Evidence from Malaysia. Paper presented at the 17th European Real Estate Society Conference 2010, Milan, 23-36 June 2010.

Mohd Ghazali, N. A. (2007). Ownership Structure and Corporate Social Responsibility Disclosure: some Malaysian evidence. Corporate Governance, 7(3), 251-266. http://dx.doi.org/10.1108/14720700710756535.

Muhammad Jamil, C. Z., Alwi, K., \& Mohamed, R. (2003). Corporate Social Responsibility Disclosure in the Annual Reports of Malaysian Companies: a Longitudital Study Analisis, 10(1), 139-159.

Muniandy, J. K., \& Barnes, L. (2010). The Link between Corporate Social Performance and Institutional Investors' Shareholdings in Malaysian Public Listed Companies. International Review of Business Research Papers, 6(4), 246-261.

Newell, G., Ting Kien, H., \& Acheampong, P. (2002). Listed Property Trusts in Malaysia. Journal of Real Estate Literature, 10(1), 109-118.

Nik Ahmad, N. N., Sulaiman, M., \& Siswontoro, D. (2003). Corporate Social Responsibility Disclosure in Malaysia: An analysis of Annual Reports of KLSE Listed Companies. IIUM Journal of Economics and Management, 11(1), 1-37.

Oh, W. Y., \& Chang, Y. K. (2011). The Effect of Ownership Structure on Corporate Social Responsibility: Empirical Evidence from Korea. Journal of Business Ethics, 104, 283-297. http://dx.doi.org/10.1007/s10551-011-0912-z.

Othman, R., \& Ameer, R. (2010). Environmental Disclosures of Palm Oil Plantation Companies in Malaysia: a Tool for Stakeholder Engagement. Corporate Social Responsibility \& Environmental Management, 17(1), 52-62. http://dx.doi.org/10.1002/csr.218.

Putrajaya Committee on GLC High Performance. (2006). The Silver Book. Retrieved from http://www.pcg.gov.my/trans_manual.asp.

Ramasamy, B., \& Ting, H. W. (2004). A Comparative Analysis of Corporate Social Responsibility Awareness. Journal of Corporate Citizenship, 13, 109-123.

Said, R., Zainuddin, Y. H., \& Haron, H. (2009). The Relationship between Corporate Social Responsibility Disclosure and Corporate Governance Characteristics in Malaysian Public Listed Companies. Social Responsibility Journal, 5(2), 212-226. http://dx.doi.org/10.1108/17471110910964496.

Saleh, M. (2009). Corporate Social Responsibility Disclosure in an Emerging Market: A Longitudinal Analysis Approach. International Business Research, 2(1), 131-141.

Saleh, M., Zulkifli, N., \& Muhamad, R. (2010). Corporate Social Responsibility Disclosure and its Relation on Institutional Ownership: Evidence from Public Listed Companies in 
Malaysia. Managerial Auditing Journal, $25(6), \quad$ 591-613. http://dx.doi.org/10.1108/02686901011054881.

Saleh, M., Zulkifli, N., \& Muhamad, R. (2011). Looking for Evidence of the Relationship between Corporate Social Responsibility and Corporate Financial Performance in an Emerging Market. Asia - Pacific Journal of Business Administration, 3(2), 165.

Singh, T. R., Yahya, S., Amran, A., \& Nabiha, S. (2009). CSR and Public Bank Bhd. (Malaysia). Global Business \& Management Research, 1(3/4), 25-43.

Smith, M., Yahya, K., \& Amiruddin, A. M. (2007). Environmental Disclosure and Performance Reporting in Malaysia. Asian Review of Accounting, 15(2), 185-199. http://dx.doi.org/10.1108/13217340710823387.

Teoh, H. Y., \& Thong, G. (1984). Another Look at Corporate Social Responsibility and Reporting: An Empirical Study in a Developing Country. Accounting, Organizations and Society, 9, 189-206.

Thompson, P., \& Zakaria, Z. (2004). Corporate Social Responsibility Reporting in Malaysia. Journal of Corporate Citizenship, 13(Spring), 125-136.

World Commission on Environment and Development. (1987). Our Common Future.

Zainal, D., Zulkifli, N., \& Saleh, Z. (2013). A Longitudinal Analysis of Corporate Social Responsibility Reporting (CSRR) in Malaysia Public Listed Firms: Pre-and-Post-Mandatory CSRR Requirement. International Journal of Advanced Research in Management and Social Science, 2(1). 